\title{
AKTIVITAS PENGHAMBATAN EKSTRAK BERBAGAI JENIS BAWANG TERHADAP PEMBENTUKAN BLACKSPOT PADA UDANG VANAME
}

\section{[Inhibition Activity of Allium spp. Extracts on Blackspot Formation of Whiteleg Shrimp]}

\author{
Tatty Yuniarti ${ }^{1,2)}$, Sukarno ${ }^{3) \star}$, Nancy Dewi Yuliana ${ }^{3)}$, dan Slamet Budijanto ${ }^{3)}$ \\ 1) Program Studi llmu Pangan, Sekolah Pascasarjana, Institut Pertanian Bogor, Bogor \\ 2) Jurusan Penyuluhan Perikanan, Sekolah Tinggi Perikanan, Bogor \\ ${ }^{3)}$ Departemen IImu dan Teknologi Pangan, Fakultas Teknologi Pertanian, Institut Pertanian Bogor, Bogor
}

Diterima 13 Januari 2018 / Disetujui 14 Mei 2018

\begin{abstract}
Blackening is a problem occurring in crustaceans, such as whiteleg shrimps (Litopenaeus vannamei), during post-mortem storage. Although blackspot seems to be harmless to consumers, it decreases the product's market value, consumer's acceptance and causes a considerable financial loss. The objective of the study was to determine the best Allium extracts from five Allium types with the ability to inhibit blackspot and apply the extracts on whiteleg shrimp. The five types of Allium were red onion (Allium cepa L. var Aggregatum), garlic (Allium sativum), yellow onion (Allium cepa Linneaus), leek (Allium fistulosum) and chives (Allium schoenoprasum L). Extraction of Allium was conducted using $80 \%$ methanol as the solvent. The dry extracts were tested in vitro using a commercial polyphenol oxidase (PPO) enzyme and a melanosis test was conducted on whiteleg shrimp treated with the extracts and stored at $0^{\circ} \mathrm{C}$ for 10 days. The results showed that the highest inhibition of blackspot formation was obtained by red onion extract at $69.79 \pm 1.91 \%$ and the lowest was by garlic extract at $14.06 \pm 1.41 \%$. The shrimps dipped in red onion extract had the lowest melanosis values and browning index values at $5.1 \pm 0.8$ and $16.76 \pm 0.94$, respectively. Red onion extract had the best ability to inhibit blackspot and has the potential to be used in shrimp.
\end{abstract}

Keywords: blackspot, onion, PPO enzyme, whiteleg shrimp

\begin{abstract}
ABSTRAK
Peristiwa blackspot adalah terbentuknya warna hitam pada udang vaname (Litopenaeus vannamei) yang terjadi selama penanganan pasca panen dan penyimpanan dingin. Blackspot menyebabkan penurunan kualitas sensori yang mengakibatkan jatuhnya harga, sehingga memerlukan bahan tambahan yang dapat menghambat laju pembentukan blackspot. Tujuan penelitian adalah menentukan ekstrak bawang terbaik dari lima jenis bawang (Allium) yang mempunyai kemampuan menghambat blackspot pada udang vaname. Kelima jenis bawang tersebut adalah bawang merah (Allium cepa L. var Aggregatum), bawang putih (Allium sativum), bawang bombai (Allium cepa Linnaeus), bawang daun (Allium fistulosum), bawang lokio (Allium schoenoprasum L.). Ekstraksi bawang menggunakan pelarut metanol $80 \%$. Ekstrak kering diuji kemampuan antiblackspot secara in vitro menggunakan enzim polifenol oksidase (PPO) komersial dan diaplikasikan pada udang vaname yang disimpan pada suhu $0^{\circ} \mathrm{C}$ selama 10 hari. Hasil penelitian menunjukkan pada penyimpanan hari ke-10, ekstrak bawang merah menghambat aktivitas enzim PPO tertinggi yaitu $69,78 \pm 1,91 \%$, dibandingan dengan ekstrak bawang lainnya. Udang yang direndam menggunakan ekstrak bawang merah mempunyai nilai melanosis dan Indeks browning terendah berturut-turut yaitu 5,1 $\pm 0,8$ dan $16,76 \pm 0,94$. Ekstrak bawang merah mempunyai kemampuan menghambat blackspot terbaik dan berpotensi untuk digunakan sebagai ingredien pangan yang berfungsi antiblackspot pada bahan pangan segar.
\end{abstract}

Kata kunci: blackspot, bawang, enzim PPO, udang vaname

\section{PENDAHULUAN}

Pembentukan browning atau blackspot biasanya terjadi pada bahan pangan segar yang tidak ditangani dengan baik. Istilah browning terjadi pada

\footnotetext{
*Penulis Korespondensi:

E-mail: dsukarno@apps.ipb.ac.id
}

buah-buahan dan sayuran segar setelah dipotong dan istilah blackspot biasanya digunakan pada peristiwa yang sama pada hewan seperti crustacea pasca panen. Pangan segar menjadi berwarna kecoklatan. Walaupun pigmen ini tidak berbahaya, tetapi dapat menurunkan tingkat penerimaan konsumen (Senapati et al., 2017). 
Pembentukan blackspot terjadi karena aktivitas enzim polifenol oksidase (PPO). Enzim ini merupakan enzim endogeneus yang terdapat secara alami pada makhluk hidup, termasuk jenis krustasea seperti udang. Pada saat hidup, enzim ini bermanfaat sebagai respon imun dan pertahanan diri (Bartolo dan Brik, 1998). Pada fase post mortem, aktivitas enzim PPO mengoksidasi senyawa fenol menjadi quinon. Quinon merupakan senyawa yang reaktif dan secara spontan membentuk polimer dengan quinon sendiri atau dengan senyawa aromatis lain sehingga membentuk melanin yang berwarna hitam (blackspot) (Chang, 2009).

Penggunaan antiblackspot pada udang dilakukan pada pascapanen maupun ketika udang masih dalam budidaya. Bahan tambahan makanan yang biasa digunakan sebagai antiblackspot adalah agent sulfur seperti sodium metabisulfit $\left(\mathrm{Na}_{2} \mathrm{~S}_{2} \mathrm{O}_{5}\right)$ (E223). Nilai Accetable Daily Intake (ADI) pada senyawa ini adalah $0,7 \mathrm{mg} / \mathrm{kg}$ berat badan. Namun residu mengonsumsi sodium metabisulfit (SMS) dapat mempengaruhi kesehatan, seperti alergi dan pemicu asma (Queiroz et al., 2008).

Upaya untuk mengatasi blackspot, dilakukan dengan pemanasan (Manheem et al., 2013), kemasan vacuum (Reddy et al., 2013), modified atmosphere packaging (MAP) (Slattery dan Palmer, 2014). Perlakuan fisik dapat memengaruhi zat gizi, penurunan komponen bioaktif, vitamin dan penampilan produk (Manheem et al., 2013) (Erkan, 2017) (Aberoumand, 2014) (Sun et al., 2015) (Okpala, 2017). Permasalahan tersebut diatasi dengan menggunakan bioaktif dari tanaman seperti ekstrak jamur (Encarnacion et al., 2011), ekstrak teh hijau (Nirmal dan Benjakul, 2012) dan ekstrak delima (Fang et al., 2013).

Komponen kimia flavonoid mengindikasikan bertanggung jawab terhadap antibrowning melaui mekanisme inhibitor kompetitif (Zhang et al., 2016). Komponen lain yang berpotensi sebagai antibrowning adalah polifenol (Krasnova et al., 2017). Kemampuan antibrowning atau antiblackspot berhubungan erat dengan kemampuan antioksidan $\mathrm{Wu}$ et al., 2010). Berbagai jenis bawang (Allium) digunakan sebagai bumbu di Indonesia (Ariyanti et al., 2018). Bawang kaya akan senyawa polifenol dan flavonoid dan mempunyai aktivitas antioksidan yang tinggi (Bhandari et al., 2014). Berdasarkan kandungan komponen bioaktif tersebut, maka diduga berbagai jenis bawang dapat menghambat pembentukan blackspot.

Penelitian bertujuan untuk melakukan screening ekstrak 5 (lima) jenis bawang yang diduga mempunyai kemampuan menghambat pembentukan blackspot, yaitu bawang merah (Allium cepa L. var Aggregatum), bawang putih (Allium sativum), bawang bombay (Allium cepa Linnaeus), bawang daun (Allium fistulosum), bawang lokio Allium schoeno-prasum L dan mengaplikasikan ekstrak bawang pada udang vaname.

\section{BAHAN DAN METODE}

\section{Bahan}

Udang vaname diperoleh dari tambak Balai Administrasi Pelatihan Perikanan Lapangan (BAPPL) Sekolah Tinggi Perikanan (STP) Serang. Berbagai jenis bawang yang dipergunakan adalah bawang merah didapatkan dari Brebes, Jawa Tengah, bawang bombai, bawang putih, bawang daun dan bawang lokio, diperoleh dari Pasar Bogor.

\section{Pembuatan ekstrak bawang (Juliani et al., 2016) dengan modifikasi}

Kelima jenis bawang masing-masing dicuci, dikeringkan dengan freeze dryer selama 24 jam, kemudian dihaluskan menjadi tepung. Tepung bawang diekstrak menggunakan metanol (Merck, USA) 80\% sebanyak $2 x$ volume, disonikasi menggunakan ultrasonic bath (Bransonic Ultrasonic Cleaner model 8510E MTH, USA) selama 30 menit, fase supernatan diambil. Ekstraksi diulangi 2x, supernatan yang dihasilkan digabung, dikeringkan menggunakan rotary evaporator (Butchi Rotavapor R-210, BÜCHII, Labortechnik, Switzerland), pada suhu $45^{\circ} \mathrm{C}$. Ekstrak kering diuji kandungan total flavonoid dan total fenolik. Kemampuan ekstrak bawang dalam menghambat blackspot diuji secara in vitro terhadap aktivitas enzim PPO komersil (Sigma Aldrich, Singapura) dan diaplikasikan pada udang vaname.

\section{Aplikasi ekstrak berbagai bawang (Teerawut dan Pratumchart, 2014)}

Udang (Litopenaeus vannamei) \pm 100 ekor $/ \mathrm{kg}$ diambil dari tambak, dimatikan secara cepat. Udang direndam dalam ekstrak berbagai jenis bawang dan sodium metabisulfit (SMS) sebagai kontrol positif, dengan konsentrasi yang sama yaitu masing-masing $1,25 \%$ (Fang et al., 2013) selama 30 menit. Udang diangkat dari larutan, segera disimpan dalam stereofoam yang dikontrol suhunya setiap hari agar tetap $0 \pm 5^{\circ} \mathrm{C}$ menggunakan es dengan perbandingan udang: es yaitu 1:2 (b/b). Es yang mencair diganti dengan es baru dalam berat yang sama setiap satu hari satu kali penggantian. Pengamatan nilai melanosis dan indeks browning dilakukan setiap 2 hari sekali selama 10 hari. Udang tanpa perlakuan ekstrak digunakan sebagai kontrol negatif.

\section{Uji total flavonoid (Gulfraz et al., 2014)}

Sebanyak $5 \mathrm{~g}$ sampel ekstrak dilarutkan dalam $50 \mathrm{~mL}$ etanol (Merck, USA) $80 \%$. Sebanyak $250 \mu \mathrm{L}$ larutan ekstrak ditambahkan 1,25 mL akuades dan $75 \mu \mathrm{L}$ larutan $\mathrm{NaNO}_{2}$ (Merck, USA) $5 \%$. Setelah 5 menit, ditambahkan $150 \mu \mathrm{L} \mathrm{AICl}{ }_{3}$ (Merck, USA) $10 \%$ 
dan setelah 6 menit ditambahkan $500 \mu \mathrm{L} \mathrm{NaOH}$ (Merck, USA) 1M dan $275 \mu \mathrm{L}$ akuades. Selanjutnya diukur absorban pada panjang gelombang $415 \mathrm{~nm}$. Standar yang digunakan adalah quercetin (Merck, HPLC Grade, USA) konsentrasi 50-250 $\mathrm{gg} / \mathrm{mL}$. Total flavonoid dinyatakan sebagai $\mathrm{mg} \mathrm{QE} / \mathrm{g}$ ekstrak.

\section{Uji total fenolik (Gulfraz et al., 2014)}

Sebanyak $5 \mathrm{mg}$ sampel ekstrak dilarutkan dalam $10 \mathrm{~mL}$ akuades, larutan diambil $1 \mathrm{~mL}$ ditambah dengan $0,2 \mathrm{~mL}$ reagen Folin Ciocalteu (Merck, USA) dan segera dihomogenisasi. Setelah 3 menit ditambahkan $3 \mathrm{~mL}$ natrium karbonat $\left(\mathrm{Na}_{2} \mathrm{CO}_{3}\right)$ (Merck, USA) $2 \%$. Kemudian setelah 30 menit disimpan pada ruang gelap, absorbannya diukur pada panjang gelombang $760 \mathrm{~nm}$ menggunakan spektrofotometer UV-VIS (UV-2450 Spectrophotometer Shimadzu, Jepang). Sebagai standar digunakan asam galat (Merck, USA) konsentrasi $0-0,05 \mathrm{mg} / \mathrm{mL}$ atau $0-500$ $\mu \mathrm{g} / \mathrm{mL}$. Total fenolik dinyatakan sebagai $\mathrm{mg} \mathrm{GAE} / \mathrm{g}$ ekstrak bawang.

\section{Uji aktivitas enzim PPO (Nirmal dan Benjakul, 2012)}

Sebanyak $400 \mu \mathrm{L}$ larutan enzim PPO komersial (5571 unit/mg dalam 4,3 mg, diencerkan hingga 2,59 unit/mg), dicampur dengan ekstrak bawang 100 $\mathrm{mg} / \mathrm{mL}$ sebanyak $400 \mu \mathrm{L}$, dibiarkan selama 30 menit. Campuran diambil sebanyak $200 \mu \mathrm{L}$, ditambah $15 \mathrm{mM}$ L-DOPA (Merck, USA) $600 \mu \mathrm{L}, 0,05 \mathrm{M}$ buffer fosfat $\mathrm{pH} 6,0400 \mu \mathrm{L}$ dan akuades $1000 \mu \mathrm{L}$. Campuran diinkubasi selama 3 menit pada suhu $45^{\circ} \mathrm{C}$. Pembentukan dopakrom diamati menggunakan spektrofotometer UV-160 (Shimadzu, Kyoto, Jepang) pada panjang gelombang $475 \mathrm{~nm}$ (A475) Satu unit aktivitas PPO didefinisikan sebagai peningkatan absorban pada A475 sebanyak 0,001/min $/ \mathrm{mL}$. Kemampuan ekstrak berbagai bawang menghambat enzim PPO secara in vitro dinyatakan sebagai persentase penghambatan enzim PPO menggunakan rumus:

$$
\% \text { Penghambatan PPO }=[(A-B) / A] \times 100 \%
$$

dimana, $\mathrm{A}=$ aktivitas PPO tanpa ekstrak dan $\mathrm{B}=$ aktivitas $\mathrm{PPO}$ dengan ekstrak.

\section{Penentuan nilai melanosis (Manheem et al., 2013)}

Pembentukan blackspot pada udang vaname diamati secara visual oleh 30 orang panelis non standar (SNI 01-2346-2006). Nilai melanosis 1-10, nilai $0=$ tidak ada pembentukan blackspot $2=$ sedikit (hingga 20\% permukaan udang terjadi blackspot); $4=$ sedang (20 sampai dengan $40 \%$ permukaan udang terjadi blackspot); $6=$ terlihat jelas (40 hingga $60 \%$ permukaan udang terdapat blackspot; $8=$ banyak sekali (60 hingga $80 \%$ permukaan udang ter- dapat blackspot); $10=$ amat sangat banyak $(80$ hingga $100 \%$ permukaan udang terdapat blackspot.

\section{Penentuan indeks browning (Palou et al., 1999)}

Penentuan warna kecokelatan (indeks browning) pada udang ditentukan menggunakan alat chromameter CR-310, Minolta, Jepang yang dikalibrasi dengan standar plat keramik berwana putih. Hasil pengukuran warna berupa data unit warna CIELab terdiri dari warna terang (ligthness) L, kemerahan (redness) a, dan kekuningan (yellowness) b yang diukur sebanyak tiga kali pengukuran per ulangan sampel. Indeks browning dapat dihitung dari:

$$
\begin{gathered}
\text { Indeks browning }=[100(X-0,31)] / 0,172 \\
X=(a+1,75 L) /(5,645 L+a-3,012 b)
\end{gathered}
$$

Indeks browning menyatakan warna coklat yang murni akibat aktivitas enzim PPO pada substrat.

\section{Analisis data}

Data yang ditampilkan adalah nilai ratarata \pm standar deviasi dari 3 kali ulangan. Data dianalisa secara statistik dengan analisis of variance (ANOVA) satu arah (One way) dan batas kepercayaan $95 \%(P<0,05)$ menggunakan software Statistical of Package for the Social Science (SPSS) versi 17.

\section{HASIL DAN PEMBAHASAN}

\section{Kandungan komponen total fenolik dan flavo- noid berbagai jenis bawang}

Hasil penelitian menunjukkan ekstrak bawang bombay mengandung total fenolik tertinggi, diikuti oleh bawang merah, daun bawang dan bawang lokio serta bawang putih, yang dapat dilihat pada Tabel 1. Komponen flavonoid terbesar terdapat pada ekstrak bawang merah, diikuti oleh bawang bombay, bawang lokio, daun bawang dan bawang putih. Penelitian ini sejalan dengan Cheng et al. (2013) yang menyatakan bahwa komponen total fenolik lebih banyak terdapat pada bawang bombay dan flavonoid lebih banyak pada bawang merah. Ekstrak air bawang merah mengandung lebih kaya komponen fitokimia, namun komponen fenolik positif terdapat pada ekstrak $80 \%$ metanol (Vandana dan Ramesh, 2017)

Perbedaan spesies bawang, perbedaan umur bawang menentukan jenis dan konsentrasi senyawa polifenol dan flavonoid (Vlase et al., 2013). Perbedaan waktu ekstraksi, jenis dan konsentrasi pelarut berpengaruh terhadap komposisi kimia ekstrak dan kemampuan bioaktif ekstrak bawang (Viera et al., 2017). Ekstraksi menggunakan metanol menghasilkan komponen polifenol dan flavonoid lebih tinggi dibandingkan dengan air, etil asetat, etanol dan hek- 
san (Widyawati et al., 2014). Penggunaan dua pelarut yang berbeda polaritasnya (binary) seperti metanol dan air dengan perbandingan tertentu (70\%) dapat mengekstrak komponen polifenol dan flavonoid yang lebih banyak, dibandingkan penggunaan pelarut tunggal (Singh et al., 2017).

Tabel 1. Konsentrasi total senyawa flavonoid dan fenolik pada ekstrak berbagai jenis bawang

\begin{tabular}{lcc}
\hline \multicolumn{1}{c}{ Ekstrak } & $\begin{array}{c}\text { Total Fenolik }^{*} \\
\text { mg GAE/ gr } \\
\text { Ekstrak }\end{array}$ & $\begin{array}{c}\text { Total } \\
\text { Flavonoid } \\
\text { QE/gr Ekstrak }\end{array}$ \\
\hline Bawang putih & $78,66 \pm 9,77^{\mathrm{a}}$ & $58,03 \pm 1,98^{\mathrm{a}}$ \\
Daun bawang & $186,68 \pm 9,18^{\mathrm{b}}$ & $79,57 \pm 1,41^{\mathrm{b}}$ \\
Bawang merah & $341,96 \pm 7,51^{\mathrm{c}}$ & $134,63 \pm 5,34^{\mathrm{e}}$ \\
Bawang bombay & $414,50 \pm 8,91^{\mathrm{a}}$ & $126,10 \pm 2,05^{\mathrm{a}}$ \\
Bawang lokio & $181,26 \pm 9,32^{\mathrm{b}}$ & $87,38 \pm 5,92^{\mathrm{c}}$ \\
\hline
\end{tabular}

Keterangan: *) Nilai rata-rata $\pm S D$ dari 3 ulangan; **) Perbedaan huruf pada kolom yang sama menunjukkan adanya perbedaan nyata $(P<0,05)$

Berbagai jenis komponen fenolik ditemukan pada berbagai bawang. Parvu et al. (2010) melaporkan dari 5 jenis bawang (Allium), keseluruhan bawang mengandung $p$-koumarik dan asam ferulik. Isoquercitrin ditemukan pada $A$. obliquum, $A$. Schoenoprasum dan $A$. fistulosum, rutin pada $A$. Senescens subsp. montanum dan $A$. Schoenoprasum, sedangkan quercetin hanya ditemukan pada $A$. fistulosum. Luteolin dan apigenin terdapat pada $A$. obliquum. Penelitian Farag et al. (2017) melaporkan bawang putih (Allium sativum) mengandung senyawa fenolik seperti asam pthalit, asam kafeik dan asam ferulik sedangkan bawang merah (Allium cepa red Cv.) mengandung senyawa quersetin-o-glukosida, kaempferol-o-glukosida, quersetin-o-rhamnosida dan isorhamnetin-o-hexoside.

\section{Kemampuan ekstrak berbagai bawang meng- hambat aktivitas enzim PPO}

Kemampuan penghambatan aktivitas enzim PPO oleh ekstrak berbagai jenis bawang, tertinggi adalah oleh ekstrak bawang merah, diikuti oleh ekstrak bawang Bombay, ekstrak bawang lokio, ekstrak bawang daun, dan ekstrak bawang putih. Aktivitas penghambatan enzim PPO oleh ekstrak metanol bawang merah lebih tinggi dibandingkan dengan ekstrak metanol kulit delima, yang menghambat aktivitas enzim tyrosinase (PPO) hinggga 50\% (Fawole et al., 2012). Hasil ini mendukung penelitian Soto et al. (2016) yang melaporkan bahwa bawang putih mempunyai kemampuan antiblackspot yang lebih rendah dibandingkan dengan bawang merah. Kemampuan ini diduga karena bawang merah mempunyai kandungan polfenol yang lebih tinggi dibandingkan bawang putih, walaupun bawang putih dan bawang merah sama sama mempunyai kemampuan antioksidan yang tinggi. Kemungkinan kemampuan antioksidan pada bawang putih disebabkan oleh senyawa organosulfur, dan kemampuan antioksidan bawang merah karena kandungan senyawa polifenol. Sehingga tidak semua komponen antioksidan bersifat antiblackspot, tetapi diduga komponen yang berperan sebagai antiblackspot adalah senyawa jenis polifenol atau flavonoid.

Nilai penghambatan aktivitas enzim PPO sebesar $69,78 \pm 1,91 \%$ dari ekstrak metanol bawang merah pada penelitian ini, lebih tinggi dibandingkan ekstrak air bawang merah terhadap enzim PPO dari terong "birgah" (Solanum melongena L.) yaitu sebesar 54,2\% (Barbagallo et al., 2012). Perbedaan pelarut dalam ekstraksi bawang merah menghasilkan komposisi kimia yang berbeda sehingga menghasilkan kemampuan aktivitas bioaktif yang berbeda (Senapati et al., 2017). Persentase penghambatan aktivitas enzim PPO oleh ekstrak berbagai jenis bawang disajikan pada Gambar 1.

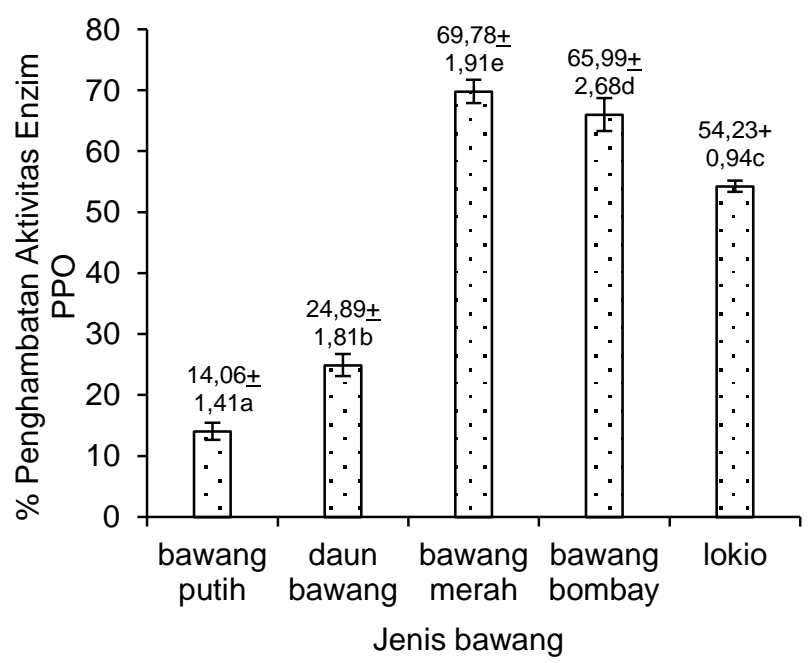

Keterangan: Perbedaan huruf menunjukkan adanya perbedaan nyata $(P<0,05)$

Gambar 1. Persentase penghambatan aktivitas enzim PPO yang diberi berbagai ekstrak bawang-bawangan

Ekstrak metanol bawang merah mempunyai kemampuan antibrowning dan antioksidan, dan mengandung fenolik dan quercetin. Komponen fenolik dan flavonoid pada bawang merah diduga sebagai senyawa yang bertanggung jawab terhadap sifat antibrowning tersebut (Roldan et al., 2008). Dugaan mekanisme penghambatan antibrowning ekstrak air berbagai jenis bawang pada enzim PPO dari umbi edible yam (Dioscorea cayenensis-rotundata cv. Kponan) antara lain penghambatan non kompetitif (ekstrak bawang merah); kompetitif (ekstrak bawang bombay); unkompetitif (ekstrak bawang putih) (Yapi, Gnangui, dan Dabonné, 2015). 


\section{Efektivitas ekstrak berbagai jenis bawang pada udang vaname}

Aplikasi ekstrak berbagai jenis bawang pada udang vaname, menunjukkan perbedaan kontrol dengan perlakuan ekstrak yang dapat dilihat pada Gambar 2. Penyimpanan hari ke-10, udang tanpa ekstrak telah sempurna mengalami melanosis pada bagian kaki, ekor dan kepala udang. Perendaman udang dalam ekstrak bawang merah mencapai nilai melanosis $5,1 \pm 0,8$, pada bagian kepala dan kaki udang melanosis belum terjadi secara sempurna, demikian pula pada bagian ekor melanosis masih sedikit terjadi. Pembentukan blackspot udang pada mulanya terjadi pada bagian kepala, selanjutnya bagian ekor, kemudian kaki dan akan sempurna ketika terjadi pada bagian punggung seperti penelitian yang dilakukan oleh (Zamorano et al., 2008). Gambar 3 menunjukkan nilai melanosis ini tidak berbeda nyata dengan perendaman udang dalam larutan sodium metabisulfit $1,25 \%$ pada hari ke-10 sebesar $5,0 \pm 0,8$.

Warna coklat adalah kombinasi dari ketiga indikator warna tersebut dan dirumuskan menjadi indeks pencoklatan (indeks browning) (Palou et al., 1999). Gambar 4 menunjukkan nilai Indeks browning meningkat pada keseluruhan udang baik dengan perlakuan maupun kontrol. Peningkatan nilai indeks browning ini karena terjadinya penurunan nilai $L$ dan penurunan nilai a, dan kenikan nilai b. Semakin rendah nilai $L$ maka semakin gelap warna sampel. Semakin rendah nilai a maka semakin membentuk warna merah. Nilai b semakin meningkat karena semakin terbentuk warna kuning. Indeks browning udang yang direndam dalam ekstrak berbagai jenis bawang dan sodium metabisulfit menunjukkan terjadinya kenaikan. Udang yang direndam dalam ekstrak bawang merah mempunyai nilai indeks browning yang terendah yaitu $16,76 \pm 0,94$, dibandingkan

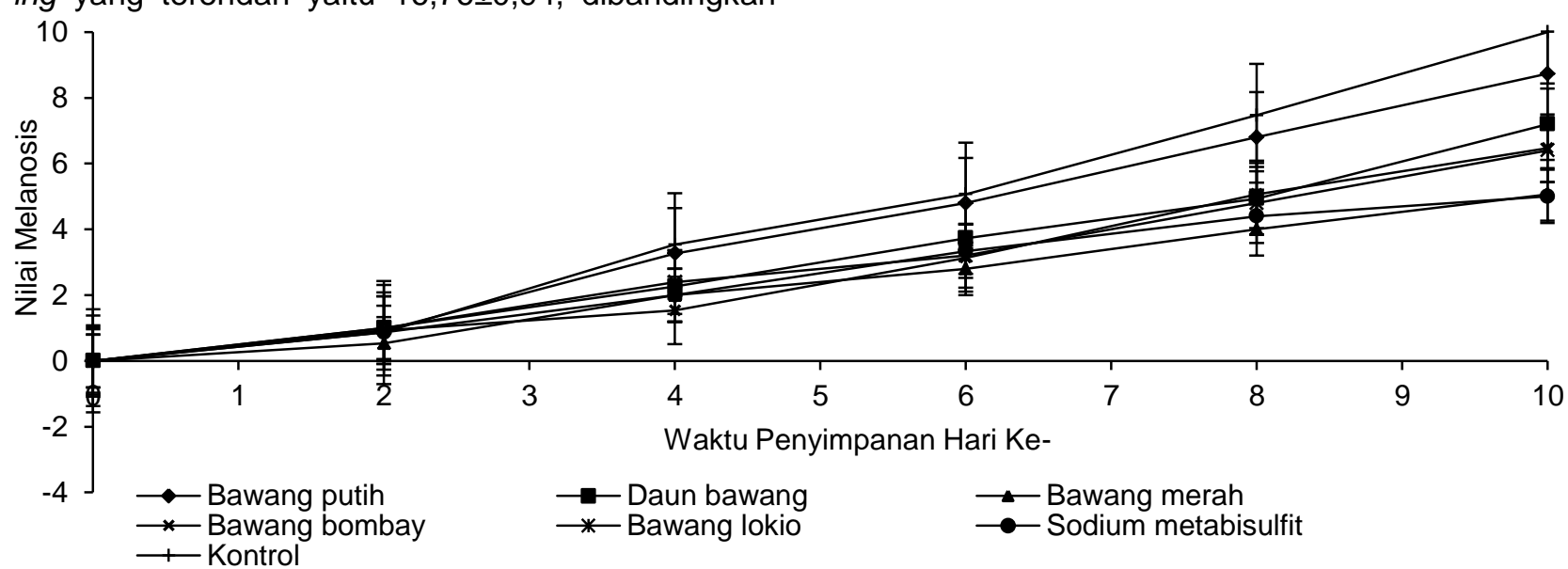

Gambar 3. Grafik laju melanosis udang vaname yang diberi ekstrak berbagai jenis bawang disimpan pada suhu $0^{\circ} \mathrm{C}$ selama 10 hari ekstrak bawang lainnya dan sodium metabisulfit pada penyimpanan hari ke-10.

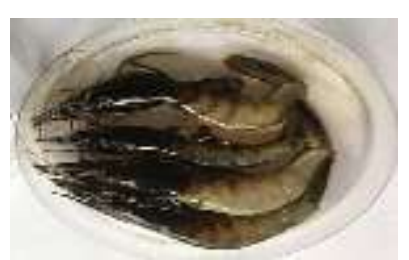

A

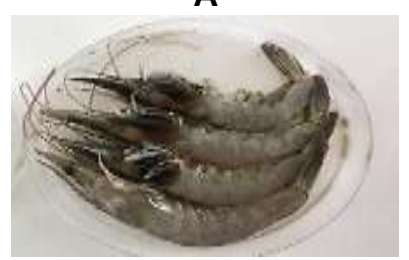

C

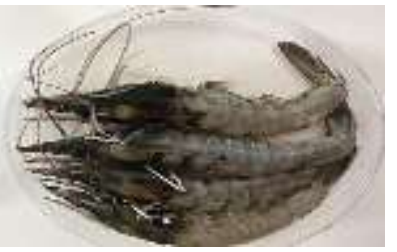

E

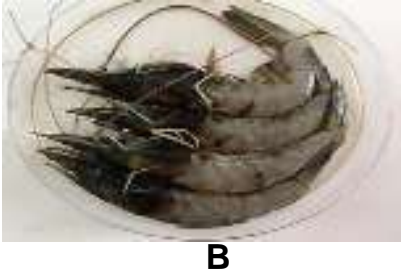

B

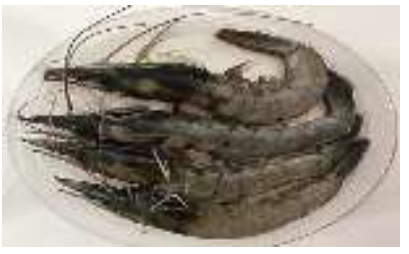

D

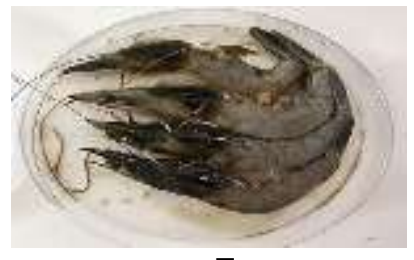

$\mathbf{F}$

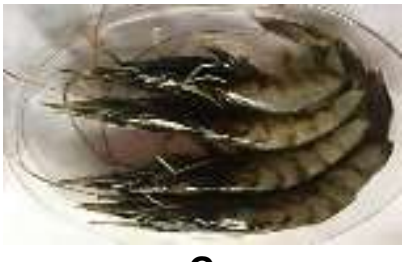

G

Gambar 2. Pembentukan blackspot pada udang vaname yang diberi ekstrak berbagai jenis bawang dan sodium metabisulfit disimpan pada suhu $0^{\circ} \mathrm{C}$ pada pengamatan hari ke-10 


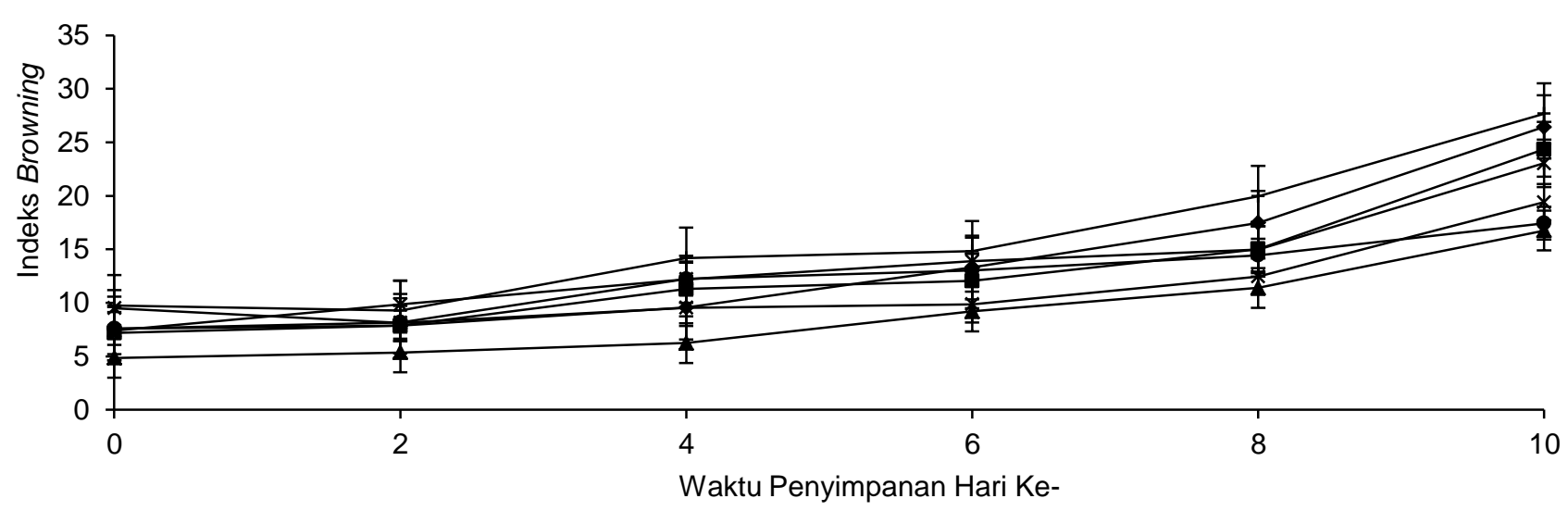

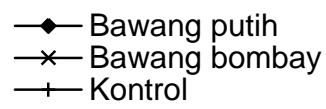

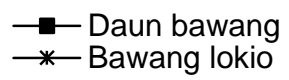

- B Bawang merah Sodium Metabisulfit

Gambar 4. Grafik perubahan indeks browning udang vaname yang diberi ekstrak bawang-bawangan, disimpan pada suhu $0^{\circ} \mathrm{C}$ selama 10 hari

Kenaikan indeks browning pada hari ke 0-4 secara umum berlangsung lambat, namun setelah itu berlangsung cepat. Enzim PPO atau enzim tyrosinase mempunyai substrat L-tyrosin, yaitu substrat monofenolik yang utama pada hewan. Tyrosin adalah monohidroksil fenol. Reaksi hidroksilasi tyrosin oleh enzim PPO membentuk dihidroksil-phenilalanin (DOPA). Reaksi hidroksilasi monofenol ini berlangsung lambat dibandingkan reaksi oksidasi difenol menjadi quinon). Quinon adalah senyawa yang sangat reaktif, dan dapat membentuk polimer secara spontan menjadi komponen dengan berat molekul besar yaitu melanin/blackspot, bereaksi dengan asam amino dan protein membentuk warna coklat (Kim et al., 2002).

\section{KESIMPULAN}

Ekstrak metanol $80 \%$ berbagai jenis bawang dapat menghambat aktivitas enzim PPO dan menghambat pembentukan blackspot. Ekstrak bawang merah mempunyai penghambatan aktivitas enzim PPO tertinggi yaitu sebesar $69,79 \pm 1,91 \%$, yang diaplikasi pada udang vaname mempunyai nilai melanosis terendah yaitu $5,1 \pm 0,8$ dan nilai indeks browning yang terendah yaitu $16,76 \pm 0,94$ pada hari ke-10 pada penyimpanan $0^{\circ} \mathrm{C}$, dibandingkan ekstrak berbagai jenis bawang lainnya. Dari hasil ini dapat disimpulkan bahwa ekstrak metanol bawang merah berpotensi untuk digunakan sebagai ingredient pangan yang mempunyai fungsi penghambat pembentukan blackspot pada udang vaname. Saran penelitian selanjutnya adalah mengenai residu metanol pada ekstrak bawang dan toksisitas ekstrak metanol bawang merah.

\section{DAFTAR PUSTAKA}

Aberoumand A. 2014. Preliminary studies on nutritive and organoleptic properties in processed fish fillets obtained from Iran. Food Sci Tech 34: 287-291. DOI: 10.1590/fst.2014.0042.

Ariyanti AN, Torikai K, Kirana RP, Hirata S, Sulistyaningsih E, Ito S, Yamauchi, N, Kobayashi N, Shigyo M. 2018. Comparative study on phytochemical variations in Japanese; varieties of bulb onions and South-East Asian Shallot Landraces. Horticult J: 63-72 DOI: 10.2503/hort j.OKD-066.

Barbagallo RN, Riggi E, Avola G, Patanè C. 2012. Biopreservation of "Birgah" eggplant from polyphenol oxidase activity assayed in vitro with onion (Allium cepa L.) by-products. Chem Engineer Trans 27: 1-6. DOI: 10.3303/CET122 7008.

Bartolo, Brik E. 1998. Some factors affecting Norway lobster (Nephrops norvegicus) cuticle polyphenol oxidase activity dan blackspot development. Int J Food Sci Tech 33: 329-36. DOI: 10. 1046/j.1365-2621.1998.00168.x.

Bhandari SR, Yoon MK, Kwak JH. 2014. Contents of phytochemical constituents and antioxidant activity of 19 garlic (Allium sativum L.) parental lines and cultivars. Hortic Environ Biote 55: 138-147. DOI: 10.1007/s13580-014-0155-x.

Chang T. 2009. An Updated review of tyrosinase inhibitors. Int J Mol Sci 10: 2440-2475. DOI: 10. 3390/ijms10062440.

Cheng A, Chen X, Jin Q, Wang W, Shi J. 2013. Comparison of phenolic content and a antioxidant capacity of red and yellow onions. Czech J Food Sci 31: 501-508. DOI: 10.17221/ 566/2012-CJFS. 
Encarnacion AB, Fagutao F, Hirayama J, Terayama M, Hirono I, Ohshima T. 2011. Edible mushroom (Flammulina velutipes) extract inhibits melanosis in Kuruma shrimp (Marsupenaeus japonicus). J Food Sci 76: 52-58. DOI: 10.111 1/j.1750-3841.2010.01890.x.

Erkan N. 2017. the Effect of active and vacuum packaging on the quality of turkish traditional salted dried fish Ciroz". J Food Heal Sci 3: 29_ 35. DOI: 10.3153/JFHS17004.

Fang X, Sun H, Huang B, Yuan G. 2013. Effect of pomegranate peel extract on the melanosis of Pacific white shrimp (Litopenaeus vannamei) during iced storage. J Food Agric Environ 11: 105-109.

Farag MA, Ali SE, Hodaya RH, El-Seedi HR, Sultani HN, Laub A, Eissa TF, Abou-Zaid FOF, Wessjohann LA. 2017. Phytochemical profiles and antimicrobial activities of Allium cepa red cv. and $A$. sativum subjected to different drying methods: A comparative MS-based metabolomics. Molecules 22: 1-18. DOI: 10.3390/molecules22050761.

Fawole OA, Makunga NP, Opara UL. 2012. Antibacterial, antioxidant and tyrosinase-inhibition activities of pomegranate fruit peel methanolic extract. BMC Complem Altern M 12: 1-11. DOI: 10.1186/1472-6882-12-200.

Gulfraz M, Imran M, Khadam S, Ahmed D, Asad MJ, Abassi KS, Irfan M, Mehmood S. 2014. A comparative study of antimicrobial and antioxidant activities of garlic (Allium sativum L.) extracts in various localities of Pakistan. Afr J Plant Sci 8: 298-306. DOI: 10.5897/AJPS11.252.

Juliani, Yuliana ND, Budijanto S, Wijaya $\mathrm{CH}$, Khatib A. 2016. Senyawa inhibitor a-glukosidase dan antioksidan dari kumis kucing dengan pendekatan metabolomik berbasis FTIR. J Teknol Industri Pangan 27: 17-30. DOI: 10.6066/jtip. 2016.27.1.17.

Kim J, Marshall M, Wei C. 2002. Polyphenoloxydase, in: Haard, N. (Ed.), Seafood enzymes: Utilization dan Influence on Postharvest Seafood Quality. 271-315. Marcel Dekker Inc, New York.

Krasnova I, Misina I, Seglina D, Aboltins A, Karklina D. 2017. Application of different anti-browning agents in order to preserve the quality of apple slices. $11^{\text {th }}$ Baltic Conference on Food Science and Technology: 106-111. DOI: 10.22616/food balt.2017.004.

Manheem K, Benjakul S, Kijroongrojana K, Faithong N. 2013. Effect of pre-cooking times on enzymes, properties, and melanosis of Pacific white shrimp during refrigerated storage. Int Aquat Res 5: 1-11. DOI: 10.1186/2008-6970-5-1.
Nirmal NP, Benjakul S. 2012. Effect of green tea extract in combination with ascorbic acid on the retardation of melanosis and quality changes of Pacific White shrimp during iced storage. Food Bioprocess Tech 5: 2941-2951. DOI: 10.1007/ s11947-010-0483-5.

Okpala COR. 2017. Changes in some proximate, colour and textural characteristics of ozoneprocessed shrimp: Combined effects of increasing ozone discharge and iced storage. Iran J Fish Sci 16: 625-638.

Palou E, Welti-chanes J, Palou E, Swanson BG. 1999. Polyphenoloxidase activity and color of blanched and high hydrostatic pressure treated banana puree polyphenoloxidase activity and color of blanched and high hydrostatic. J Food Sci 64: 42-45. DOI: 10.1111/j.1365-2621.1999. tb09857.x.

Parvu M, Toiu A, Vlase L, Parvu EA. 2010. Determination of some polyphenolic compounds from Allium species by HPLC-UV-MS. Nat Prod Res 24: 1318-1324. DOI: 10.1080/ 14786410903309484.

Queiroz C, Lúcia M, Lopes M, Fialho E, Valentemesquita VL. 2008. Polyphenol oxidase: characteristics and mechanisms of browning control polyphenol oxidase: characteristics and mechanisms of browning control. Food Rev Int 24: 361-375. DOI: 10.1080/875591208020893 32.

Reddy VKS, Shinde PA, Sofi FR. 2013. Effect of antimelanotic treatment and vacuum packaging on melanosis and quality condition of ice storage farmed tiger shrimp (Penaeus monodon). SAARC J Agric 11: 33-47. DOI: 10.3329/sja.v 11 i2.18400.

Roldan E, de Ancos B, Sancez-Moreno C, Cano MP. 2008. Characterisation of onion (Allium cepa L.) by-products as food ingredients with antioxidant and antibrowning properties. Food Chem 108: 907-916. DOI: 10.1016/j.foodchem. 2007.11.058.

Senapati SR, Kumar GP, Singh CB, Xavier KAM, Chouksey M, Nayak BB, Balange AK. 2017. Melanosis and quality attributes of chill stored farm raised whiteleg shrimp (Litopenaeus vannameI). J Appl Nat Sci 9: 626-631. DOI: 10.31018/jans.v9i1.1242.

Singh V, Krishan P, Shri R. 2017. Extraction of antioxidant phytoconstituents from onion waste. J Pharmacogn Phytochem 6: 502-505.

Slattery SL, Palmer PJ. 2014. Modified atmosphere packaging (MAP) for control of black spot formation in chilled prawns. J Aquat Food Prod T 23: 475-488. DOI: 10.1080/10498850.2012. 729256. 
Soto VC, González RE, Sance MM, Galmarini CR. 2016. Edible alliaceae organosulfur and phenolic content of garlic (Allium sativum L.) and onion (Allium cepa L.) and its relationship with antioxidant activity. Acta Hortic 1143: 277290. DOI: 10.17660/ActaHortic.2016.1143.39.

Widyawati SP, Budianta TDW, Kusuma FA, Wijaya EL. 2014. Difference of solvent polarity to phytochemical content and antioxidant activity of Pluchea indicia less leaves extracts. Int $\mathrm{J}$ Pharmacogn Phytochem Res 6: 850-855.

Sun Y, Zhong L, Cao L, Lin W, Ye X. 2015. Sonication inhibited browning but decreased polyphenols contents and antioxidant activity of fresh apple (Malus pumila mill, cv. Red Fuji) juice. J Food Sci Tech 52: 8336-8342. DOI: 10. 1007/s13197-015-1896-y.

Teerawut S, Pratumchart B. 2014. Effect of EDTA on Physical and Sensory Properties of Pacific White Shrimp (Litopenaeus vannamei) during Ice Storage. Thammasat Int J Sci Technol 19: 72-82.

Vandana S, Ramesh K. 2017. In vitro antioxidant and phytochemical analysis of methanolic and aqueous extract of Allium cepa. Int J Recent Sci Res 8: 21923-21928. DOI: 10.24327/IJRSR.

Viera VB, Piovesan N, Rodrigues JB, Mello R de O, Prestes RC, dos Santos RCV, Vaucher R de A, Hautrive TP, Kubota EH. 2017. Extraction of phenolic compounds and evaluation of the antioxidant and antimicrobial capacity of red onion skin (Allium cepa L.). Int Food Res J 24: 990999.

Vlase L, Parvu M, Parvu EA, Toiu A. 2013. Phytochemical analysis of Allium fitolusum $\mathrm{L}$. and A.ursinum L. Dig J Nanomater Bios 8: 457-467.

Wu L, Jou A, Chen S, Tien C, Cheng C, Fan N, Ho J. 2010. Antioxidant, anti-inflammatory and antibrowning activities of hot water extracts of oriental herbal teas. Food Funct 1: 200-208. DOI: $10.1039 / \mathrm{cofo} 00047 \mathrm{~g}$.

Yapi JC, Gnangui SN, Dabonné S. 2015. Inhibitory effect of onions and garlic extract on the enzymatic browning of an Edible Yam (Dioscorea cayenensis-rotundata cv . Kponan ) cultivated in Côte d Ivoire. Int J Curr Res Acad 3: 219-231.

Zamorano JP, Martinez-Alfarez $\mathrm{O}$, Montero $\mathrm{P}$, Gomez-Guillen, M del C. 2008. Characterisation and tissue distribution of polyphenol oxidase of deepwater pink shrimp (Parapanaeus longirostris). Food Chem 112: 1-8. DOI: 10. 1016/j.foodchem.2008.05.061.

Zhang L, Tao G, Chen J, Zheng ZP. 2016. Characterization of a new flavone and tyrosinase inhibition constituents from the twigs of Morus alba L. Molecules 21: 2-9. DOI: 10.3390/molecules 21091130. 